\title{
Struktur Komunitas Zooplankton di Perairan Pulau Panjang dan Teluk Awur, Kabupaten Jepara
}

\author{
Rodhiyah Patmawati", Hadi Endrawati, Adi Santoso \\ Departemen Ilmu Kelautan, Fakultas Perikanan dan Ilmu Kelautan, Universitas Diponegoro \\ Jl. Prof. Sudarto, SH, Tembalang, Semarang, Jawa Tengah, 50275 \\ Email: rodhiiagaiin@gmail.com
}

\begin{abstract}
Abstrak
Perairan Pulau Panjang dan Teluk Awur merupakan lokasi wisata dan dimanfaatkan masyarakat sebagai sumber mata pencaharian. Zooplankton berperan sebagai konsumen tingkat satu yang menghubungkan fitoplankton dengan organisme tingkat tinggi. Tujuan dari penelitian ini adalah untuk mengetahui komposisi, kelimpahan, indeks keanekaragaman, indeks keseragaman, indeks dominansi zooplankton di perairan Pulau Panjang dan teluk Awur. Metode yang digunakan dalam penelitian ini adalah deskriptif eksploratif dan penentuan lokasi menggunakan metode purposif sampling. Penelitian ini terbagi atas 5 stasiun dengan 3 sub-stasiun di setiap stasiun. Pengambilan sampel zooplankton dengan cara aktif dengan menarik planktonet secara horizontal. Pengambilan sampel dilakukan pada bulan Januari 2017. Hasil penelitian diperoleh 31 genera zooplankton dari 8 fila di perairan Pulau Panjang dan 20 genera zooplankton dari 3 fila di perairan Teluk Awur. Kelimpahan rata-rata zooplankton berkisar antara 378 Ind/L - 892 Ind/L di perairan Pulau Panjang dan $341 \mathrm{Ind} / \mathrm{L}$ - 446 Ind/L di perairan Teluk Awur. Indeks Keanekaragaman zooplankton menunjukkan nilai 2,36 - 2,68 di perairan Pulau Panjang dan 2,29 - 2,62 di perairan Teluk Awur yang termasuk dalam kategori sedang. Indeks keseragaman zooplankton menunjukkan nilai 0,75 0,88 di perairan Pulau Panjang dan 0,89 - 0,94 di perairan Teluk Awur yang termasuk dalam kategori Tinggi. Indeks dominansi di kedua lokasi menunjukkan tidak ada genus tertentu yang mendominasi dengan nilai $0,12-0,25$ di perairan Pulau panjang dan 0,07-0,11 di perairan Teluk Awur.
\end{abstract}

Kata Kunci: Struktur Komunitas, Zooplankton, Pulau Panjang, Teluk Awur

\section{Abstract}

\section{The Zooplankton Community Structure in Long Island Waters and Awur Bay,Regency of Jepara}

Panjang Island and Teluk Awur waters are a marine tourism places and both are also utilized as a source of community livelihood. Zooplankton role is as the first-level consumer that connects phytoplankton with the high-level organisms. The purpose of this research was to observed the compotition, abundance, diversity index, evennes index and dominance index of zooplankton in the waters of Panjang Island and Teluk Awur of Jepara Regency. This research used descriptive exploration method while location was determinated by purposive sampling method. This study was divided into 5 stations and with 3 sub-stations at each station. Zooplankton sampling was horizontally active by pulling the plankton-net. Sampling was done in january 2017. The results found 31 zooplankton genera of 8 phyla in Panjang Island waters and 20 zooplankton genera of 3 phyla in Teluk Awur waters. The average abundance ranged from 378-892 ind/L in Panjang Island waters and 341-446 ind/L in Teluk Awur waters. The zooplankton Diversity Index indicated the values of 2.36 - 2.68 in Panjang Island waters and 2.29-2.62 in Teluk Awur waters which were in the medium category. The zooplankton evenness index indicated a value of 0.75-0.88 in Panjang Island waters and 0.890.94 in Teluk Awur waters belonging to the High category. The dominance index at both sites indicated that no particular genus dominating with the values of 0.12 - 0.25 in Panjang Island waters and 0.07-0.11 in Teluk Awur waters.

Keywords: Community Structure, Zooplankton, Panjang Island, Teluk Awur

\begin{tabular}{lll}
\hline *Corresponding author & http://ejournal.undip.ac.id/index.php/buloma & Diterima/Received : 20-12-2017 \\
buloma.undip@gmail.com & & Disetujui/Accepted : 02-02-2018
\end{tabular}




\section{PENDAHULUAN}

Ekositem yang terdapat di perairan Pulau Panjang dan Teluk Awur adalah mangrove, lamun, dan terumbu karang. Pulau Panjang merupakan perairan yang terbuka sehingga sangat dipengaruhi oleh arus dan gelombang sedangkan Teluk Awur merupakan perairan dangkal yang kekuatan arus dan gelombang akan berkurang ketika sampai di pantai dengan kondisi perairan dibagian tertentu terlihat keruh (Hibatul, 2010; Setyawati et al., 2014).

Zooplankton berperan sebagai konsumen tingkat pertama yang menghubungkan fitoplankton dengan konsumen tingkat lebih tinggi, serta dapat mempengaruhi kompleks atau tidaknya rantai makanan didalam suatu ekosistem perairan (Arinardi et $a .=l$., 1996).

Keberadaan plankton dalam suatu perairan dapat digunakan untuk mengetahui tingkat produktivitas suatu perairan (Odum, 1993; Romimohtarto dan Juwana, 2007), karena kelimpahan zooplankton dapat menggambarkan keadaan suatu perairan maupun ketersediaan makanan untuk menunjang kehidupan biota, sehingga produktivitas perairan dapat dilihat dari struktur komunitas zooplankton.

Perairan Pulau Panjang dan Teluk Awur dijadikan salah satu lokasi wisata bahari di Jepara selain itu perairan tersebut juga dimanfaatkan oleh masyarakat sekitar sebagai lokasi menangkap ikan, seperti membangun karamba jaring apung dan menjaring ikan. Keberadaan ikan di perairan Pulau Panjang dan Teluk Awur tergantung pada ketersediaan makananya. Aktivitas wisatawan dan penangkapan ikan dikhawatirkan akan mempengaruhi kualitas perairan dan menyebabkan penurunan produktivitas perairan dan perubahan komposisi dan kelimpahan zooplankton.

Mengingat pentingnya peranan zooplankton sebagai produsen sekunder yang menghubungkan fitoplankton dengan organisme lainnya, sehingga dilakukan penelitian tentang struktur komunitas zooplankton untuk mengetahui komposisi, kelimpahan, indeks keanekaragaman, indeks keseragaman dan indeks dominansi zooplankton.

\section{MATERI DAN METODE}

Materi yang digunakan dalam penelitian ini adalah sampel air laut dan data parameter lingkungan (suhu, salinitas, kecerahan, oksigen terlarut, nitrat, fosfat dan $\mathrm{pH}$ ). Data pendukung yang digunakan adalah data arus dan gelombang yang diperoleh dari BMKG Semarang.
Penelitian ini dilaksanakan pada bulan Januari 2017 di perairan Pulau Panjang dan Teluk Awur, Kabupaten Jepara. Metode yang digunakan dalam peneltian ini adalah metode deskriptif eksploratif dimana metode ini bertujuan untuk membuat pencanderaan secara sistematik, faktual dan akurat mengenai fakta-fakta dan sifat-sifat suatu populasi tertentu dilingkungan tertentu (Suryabrata, 1992).

Metode yang digunakan untuk penentuan lokasi sampling adalah purposive sampling method yaitu mengambil beberapa lokasi dengan pertimbangan keadaan lingkungan yang ada di lapangan dengan kelompok kunci yang mewakili keseluruhan (Hadi, 1993). Penelitian ini terbagi atas 5 stasiun dengan 3 sub-stasiun disetiap lokasi dengan asumsi dapat mewakili perairan tersebut (Gambar 1.)

Pengambilan sampel dilakukan secara aktif dengan menarik planktonet secara horizontal (Fachrul, 2008). Identifikasi sampel dilakukan dengan bantuan mikroskop perbesaran 40x, sampel diletakkan di sedgwick rafter. Sampel kemudian diamati jumlah dan diidentifikasi genusnya yang mengacu pada buku identifikasi dari Yamaji (1979).

Data zooplankton dianalisa dengan menghitung Kelimpahan (K), Indeks Keanekaragaman (H'), Indeks Keseragaman (e) dan Indeks Dominansi (C). Kelimpahan Zooplankton dihitung menggunakan rumus menurut Arinardi et al, (1997). Indeks keanekaragaman dapat dihitung dengan rumus Shannom- Weaver (1963) dalam Arinardi et al., 1997. Untuk menghitung Indeks keseragaman menggunakan rumus dari Odum (1993). Menghitung indeks dominansi dapat menggunakan rumus dari Odum (1993).

\section{HASIL DAN PEMBAHASAN}

Hasil pengamatan zooplankton yang telah dilaskanakan di Perairan Pulau Panjang dan Teluk Awur, Kabupaten Jepara. diperoleh 31 Genera dari 8 Fila, yaitu Filum Arthropoda, Filum Mollusca, Filum Annelida, Filum Chaegtonata, Filum Chordata, Filum Protozoa, Filum Echinodermata, Filum Cnidaria di Perairan Pulau panjang dan 20 Genera dari 3 Fila, yaitu Filum Arthropoda, Filum Chaegtonata, Filum Mollusca di Perairan Teluk Awur.

Jumlah genus yang ditemukan di perairan Pulau Panjang di stasiun I yaitu 21 genera, di stasiun II dan III sebanyak 17 genera, di stasiun IV adalah 22 genera dan di stasiun V sebesar 23 genera. Sedangkan di Teluk Awur di satsiun I dan 
III dengan jumlah sama yaitu 13 genera, di stasiun II sebanyak 17 genera, di stsiun IV sebesar 14 genera dan di stasiun 5 sebanyak 16 genera (Gambar 2).

Hasil pengamatan terhadap kelimpahan zooplankton di perairan Pulau Panjang berkisar antar $378-892 \mathrm{Ind} / \mathrm{L}$ sedangkan di Teluk Awur berkisar antara 341 - 446 Ind/L. Kelimpahan zooplankton di perairan Pulau Panjang menunjukkan kelimpahan tertinggi di stasiun IV sebesar $892 \mathrm{Ind} / \mathrm{L}$ dan terendah terdapat di stasiun III yaitu 78 Ind/L. sedangkan kelimpahan di perairan Teluk Awur tertinggi terdapat di stasiun I sebesar 446 Ind/L dan kelimpahan terendah terdapat di stasiun 3 yaitu $341 \mathrm{Ind} / \mathrm{L}$ (Gambar 3.)

Hasil pengamatan terhadap indeks keanekaragaman zooplankton di perairan Pulau Panjang tertinggi terdapat di stasiun I sebesar 2,68 dan terendah terdapat di stasiun III yaitu 2,40.
Sedangkan di Perairan Teluk Awur Nilai Indeks Keanekaragaman tertinggi berada di stasiun II sebesar 2,62 dan terendah di stasiun III yaitu 2,29.

Hasil pengamatan terhadap zooplankton di Perairan Pulau Panjang diperoleh nilai indeks keseragaman tertinggi terdapat di stasiun I sebesar 0,88 dan terendah terdapat di stasiun $\mathrm{V}$ yaitu 0,75 . Sedangkan nilai indeks keseragaman yang diperoleh di Perairan Teluk Awur tertinggi terdapat di stasiun $\mathrm{V}$ sebesar 0,94 dan terendah di stasiun III yaitu 0,89 .

Hasil pengamatan zooplankton di Pulau Panjang diperoleh hasil nilai indeks dominansi tertinggi terdapat di stasiun $\mathrm{V}$ sebesar 0,25 dan terendah terdapat di stasiun I yaitu 0,12. Sedangkan di perairan Teluk Awur nilai indeks dominansi tertinggi terdapat di stasiun III sebesar 0,11 dan terendah terdapat di stasiun IV dan V dengan nilai indeks sama yaitu 0,07 .

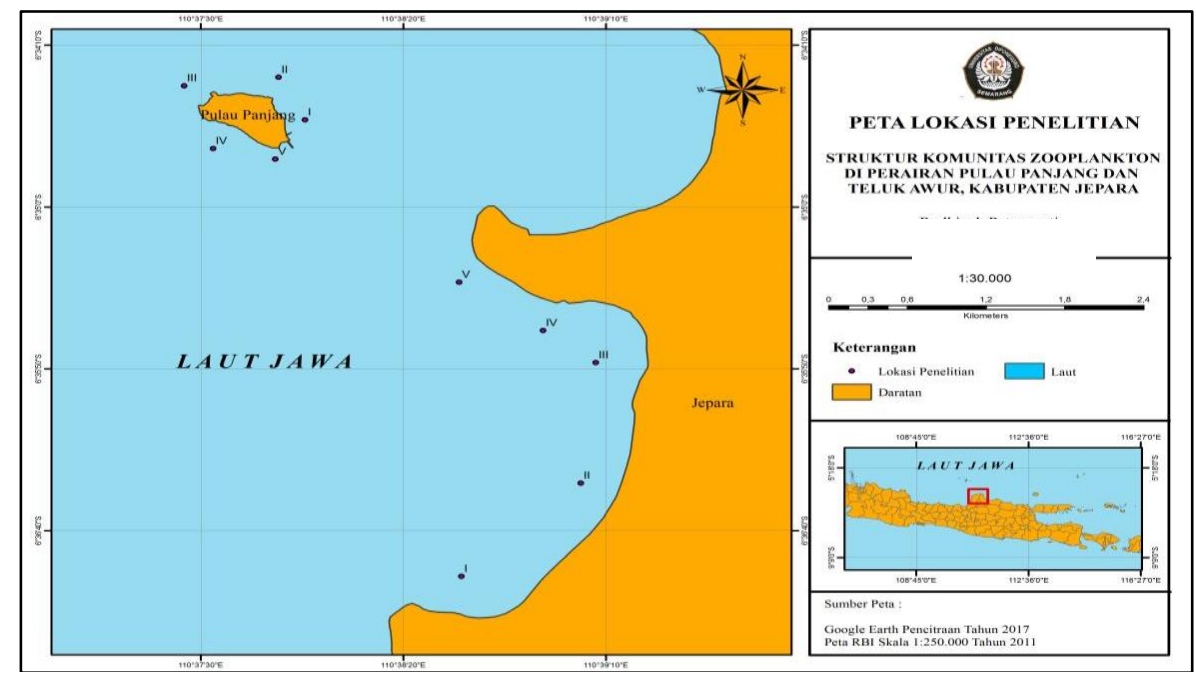

Gambar 1. Peta Penelitian di Pulau Panjang dan Teluk Awur, Kabupaten Jepara

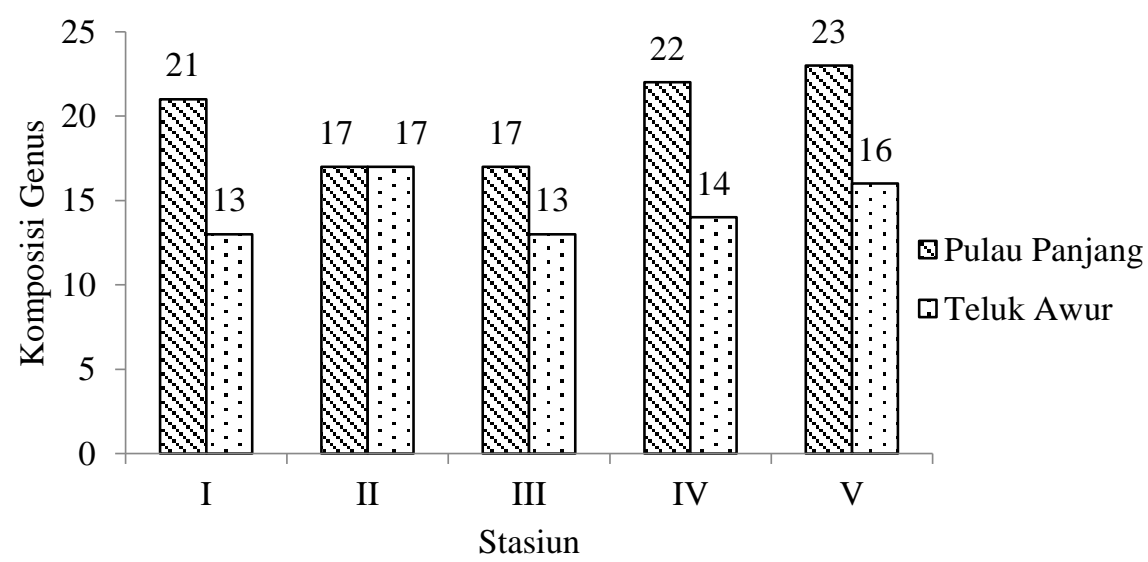

Gambar 2. Komposisi Genus Zooplankton di Perairan Pulau Panjang dan Teluk Awur, Kabupaten Jepara 


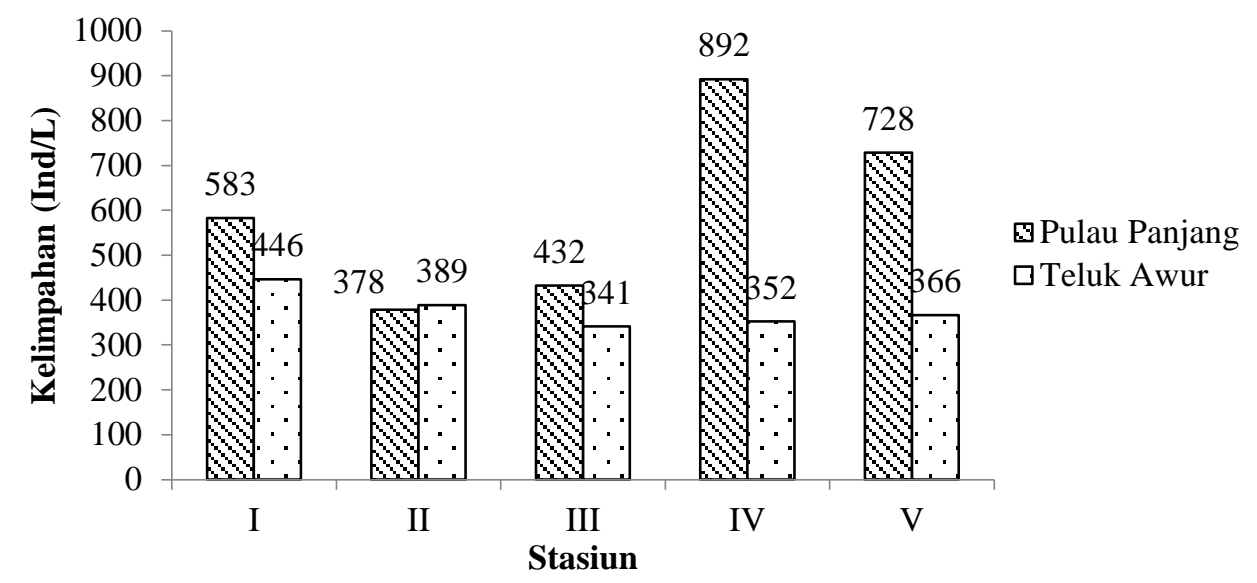

Gambar 3. Kelimpahan Zooplankton (Ind/L) di perairan Pulau Panjang dan Teluk Awur, Kbupaten Jepara.

Tabel 1. Indeks Keanekaragaman (H'), Indeks Keseragaman (e), dan Indeks Dominansi (D) Zooplankton di Perairan Pulau Panjang dan Teluk Awur, Kabupaten Jepara

\begin{tabular}{ccccccc}
\hline \multicolumn{7}{c}{ Pulau Panjang } \\
\hline Stasiun & H' $^{\prime}$ & Kategori* & $\mathrm{e}$ & Kategori** & $\mathrm{D}$ & Kategori** \\
\hline I & 2,68 & Sedang & 0,88 & Tinggi & 0,12 & TAD \\
II & 2,45 & Sedang & 0,87 & Tinggi & 0,13 & TAD \\
III & 2,40 & Sedang & 0,85 & Tinggi & 0,15 & TAD \\
IV & 2,50 & Sedang & 0,81 & Tinggi & 0,20 & TAD \\
V & 2,36 & Sedang & 0,75 & Tinggi & 0,25 & TAD \\
\hline \multicolumn{7}{c}{ Teluk Awur } \\
\hline Stasiun & H' & Kategori* & e & Kategori** & D & Kategori** \\
\hline I & 2,36 & Sedang & 0,92 & Tinggi & 0,08 & TAD \\
II & 2,62 & Sedang & 0,92 & Tinggi & 0,08 & TAD \\
III & 2,29 & Sedang & 0,89 & Tinggi & 0,11 & TAD \\
IV & 2,45 & Sedang & 0,93 & Tinggi & 0,07 & TAD \\
V & 2,61 & Sedang & 0,94 & Tinggi & 0,07 & TAD \\
\hline
\end{tabular}

TAD : Tidak Ada Dominasi

*Ludwigh et al., $1988 * *$ Krebs, 1972

Hasil komposisi zooplankton yang diperoleh menunjukkan perbedaan jumlah antar lokasi. Menurut Arinardi et al. (1997), bahwa perbedaan selang waktu yang pendek dalam pengambilan sampel akan menunjukkan adanya variasi yang cukup tinggi, hal ini dikarenakan adanya variasi faktor lingkungan seperti pasang surut, gelombang dan arus yang pada akhirnya akan mempengaruhi distribusi plankton. Selanjutnya Davis (1955), menyatakan bahwa penyebaran plankton dipengaruhi oleh faktor fisis seperti aliran air, arus, kedalaman, dan proses up welling yang menyebabkan bervariasinya nitrat dan juga menyebabkan terjadinya percampuran massa air.

Perairan Teluk Awur merupakan perairan dangkal yang mendapat serta adanya sedimentasi yang tinggi mengakibatkan kecerahan menjadi rendah Menurut Simanjuntak (2009), kecerahan dan sedimentasi akan berpengaruh terhadap intensitas cahaya yang dibutuhkan oleh fitoplankton untuk melakukan fotosintesis, dan akibatnya akan menurunkan jumlah populasi zooplankton. Menurut Arinardi et al, (1997) bahwa jumlah zooplankton sangat dipengaruhi oleh kekeruhan. Bila semakin tinggi kekeruhan maka fitoplankton tidak efektif untuk melakukan fotosintesis, akibatnya zooplankton yang memanfaatkan fitoplankton sebagai makanannya akan terganggu pertumbuhannya dan zooplankton akan saling memangsa satu sama lain sehingga hanya kelompok tertentu saja yang mampu bertahan.

Filum Arthropoda adalah filum yang selalu ditemukan di kedua lokasi. Genus yang paling sering ditemukan disemua lokasi penelitian adalah 
genus dari kelas Crustacea subkelas Kopepoda. Menurut Odum (1993), bahwa keseluruhan zooplankton di laut didominasi oleh jenis-jenis Crustacea, baik dalam jumlah individu maupun jumlah jenisnya. Serta, pendapat Arinardi et al,(1996) bahwa dominasi Crustacea pada perairan berkaitan dengan sifat omnivora atau pemakan segala (Fitoplankton, Zooplankton, Detritus), sehingga mudah untuk mendapat makanan. Ditambahkan pendapat Davis (1955), menyatakan bahwa zooplankton dari subkelas kopepoda merupakan zooplankton yang mempunyai toleransi yang sangat tinggi terhadap lingkungan perairan.

Komposisi dan kelimpahan zooplankton selain dipengaruhi oleh makanan yang terdapat di perairan tersebut juga dapat disebabkan oleh distribusi dan migrasi zooplankton (Krebs, 1972). Dalam penelitian ini komposisi dan kelimpahan zooplankton lebih banyak di Pulau Panjang diguga karena lokasi perairan Pulau Panjang lebih terbuka dari Teluk Awur sehingga arus dan gelombang lebih besar dan mempengaruhi distribusi zooplankton. Hal ini di nyatakan oleh Arshad et al, (2010) diantara semua parameter lingkungan, arus merupakan salah satu faktor utama yang mengendalikan distribusi dan kelimpahan dari banyak organisme termasuk zooplankton.

Kelimpahan zooplankton di Pulau Panjang tertinggi terdapat di Staiun IV dengan kelimpahan sebesar 890 Ind/L, dan di Teluk Awur terdapat di Staiun I dengan kelimpahan 446 Ind/L. Hal ini dijelaskan Odum (1993), pada umumnya organisme samudra akan mencapai kelimpahan maksimum pada kisaran salinitas $30 \mathrm{ppt}-35 \mathrm{ppt}$. Dimana dikedua stasiun memiliki kisaran salinitas yang baik yaitu 32,9 ppt - 33,0 ppt di Pulau Panjang dan 32,3 - 32,8 ppt di Teluk Awur.

Kelimpahan terendah di Pulau Panjang terdapat di Stasiun II (378 Ind/L) dan di Teluk Awur di Stasiun III (341 Ind/L), hal ini dikarenakan kedua stasiun memiliki DO relatif tinggi dan suhu yang relatif rendah. Secara fisiologis perbedaan suhu perairan akan berpengaruh terhadap kelangsungan hidup, dan ukuran dewasa zooplankton. Menurut Barus (2004) suhu suatu perairan akan mempengaruhi kelarutan oksigen terlarut yang sangat diperlukan organisme akuatik untuk metabolisme. Semakin tinggi suhu suatu perairan, kelarutan oksigen semakin menurun.

Menurut Arinardi et al. (1997), dimana tingginya kelimpahan zooplankton dipengaruhi oleh kelimpahan fitoplankton yang merupakan akibat dari tingginya kandungan unsur hara terutama nitrat dan fospat yang didukung oleh kondisi lingkungan perairan. Serta pendapat dari Fachrul (2007), kandungan nitrat fosfat memang tidak secara langsung mempengaruhi kelimpahan zooplankton, tetapi berpengaruh terhadap kesuburan perairan yang berkaitan dengan kehidupan fitoplankton, dimana fitoplankton memanfaatkan nutrien sebagai makanan melalui proses fotosintesis dan akan menghasilkan bahan organik, hal tersebut akan menjadikan perairan subur dengan kelimpahan fitoplankton yang cukup tinggi, sehingga mengakibatkan zooplankton melimpah di daerah tersebut.

Indeks keanekaragaman dikedua lokasi termasuk dalam kategori sedang. Menurut Odum (1993) keanekaragaman jenis yang dikatakan rendah jika penyebarannya tidak merata dan terdapat jenis tertentu yang ditemukan dalam jumlah melimpah namun ada pula jenis tertentu yang jarang ditemukan, Sebaliknya keanekaragaman jenis yang tinggi diduga karena kemampuan sejumlah genus untuk memanfaatkan dan bertoleransi terhadap faktor lingkungan perairan, sehingga produktivitas cukup tinggi, sedangkan biota yang memiliki keanekaragaman rendah diduga karena tidak mampu untuk bersaing dalam pencarian pakan.

Nilai indeks keseragaman di kedua lokasi menunjukkan kategori sedang Basmi et al (2000); Pirzan et al (2005), menyatakan apabila mengkaitkan antara kondisi komunitas dengan lingkungan, indeks keseragaman yang mendekati 0 cenderung menunjukkan komunitas yang tidak stabil. Hal tersebut dapat terjadi apabila kondisi lingkungan tidak mendukung untuk kehidupan biota di lingkungan tersebut. Sebaliknya jika indeks keseragaman mendekati 1, maka komunitas dalam kondisi stabil. Hal ini menunjukkan kondisi habitat yang dihuni relatif baik untuk pertumbuhan dan perkembangan spesies. Berdasar pernyataan diatas, berarti apabila nilai indeks keseragaman dalam suatu komunitas termasuk kategori stabil, hal ini diduga bahwa kondisi habitat yang dihuni masih dalam kondisi yang baik untuk pertumbuhan dan perkembangan.

Indeks dominansi adalah penggambaran mengenai perubahan struktur komunitas suatu perairan untuk mengetahui peranan suatu sistem komunitas serta efek gagguan pada komposisi dan strukturnya (Ahmad, 2014). Nilai indeks dominasi di Perairan Pulau panjang dan Teluk Awur termasuk dalam kategori tidak ada yang mendominasi. Hal ini diperkuat dengan 
pernyataan Krebs (1972), nilai indeks yang mendekati 0 menunjukkan tidak adanya dominansi genus tertentu dalam suatu komunitas, sedangkan adanya dominansi ditunjukkan dengan nilai indeks dominansi yang mendekati 1 .

\section{KESIMPULAN}

Berdasarkan penelitian yang dilakukan di perairan Pulau Panjang dan Teluk Awur, Kabupaten Jepara. Zooplankton yang ditemukan 31 genera dari 8 fila di Pulau Panjang dan 20 genera dari 3 fila di Teluk Awur. Terdiri dari Filum Protozoa, Arthopoda, Mollusca, Echinodermata, Chaetognatha, Annelida, Chordata, dan Cnidaria.Kelimpahan zooplankton berkisar antara 378 - 892 Ind/L di Pulau Panjang dan 341 - 446 ind/L di Teluk Awur. Hasil kelimpahan antar kedua lokasi tertinggi didapat di Pulau Panjang dan teredah di Teluk Awur.Nilai Indeks Keanekaragaman di Pulau Panjang maupun Teluk Awur termasuk dalam kategori sedang, Indeks Keseragaman di Pulau Panjang dan Teluk Awur termasuk dalam kategori tinggi, dan Indeks Dominasi di Pulau Panjang maupun Teluk Awur menunjukkan tidak ada genus yang mendominasi.

\section{DAFTAR PUSTAKA}

Ahmad, O.Z., Endrawati H,.,\& Taufiq, N., 2014. Struktur Komunitas Zooplankton pada Daerah Pertambakan di Desa Mangunharjo, Kecamatan Tugu, Kota Semarang. Journal of Marine Research, 3(3):147-154

Arinardi, O. H., Sutomo, A. B., Yusuf, S. A., Trimaningsih, E. A., \& Riyono, S. H. 1997. Kisaran kelimpahan dan komposisi plankton predominan di Perairan Kawasan Timur Indonesia. P3O-LIPI. Jakarta.

Arshad, A., Amin, S.M.N. \& Osman, N. 2010. Polution Parameters of Planktonic Shrimp, Lucifer Intermedius (Decapoda: Sergestidae) From Sungai Pulai Seagrass Area Johor, Penisular Malaysia. Sains Malaysiana 39(6):877-882

Barus, T.A. 2004. Faktor-faktor Lingkungan Abiotik Dan Keanekaragaman Plankton Sebagai Indikator Kualitas Perairan Danau Toba (Environmental Abiotic Factors and the Diversity of Plankton as Water Quality Indicators in Lake Toba, North Sumatera, Indonesia). Jurnal Manusia dan Lingkungan, 11(2):64-72.

Basmi, J. 2000. Planktonologi: plankton sebagai bioindikator kualitas perairan. Fakultas
Perikanan Dan Ilmu Kelautan, Institut Pertanian Bogor, Bogor.

Davis, C.C. 1955. The Mrine and Freshwater Plankton. Michigan State University Press. USA.

Fachrul, M.F. 2008. Metode Sampling Bioekologi. Bumi Aksara. Jakarta.

Hadi, 1993. Metodologi Research, Penulisan Paper, Skripsi, Thesis dan Disertasi. Yayasan Penerbit Fakultas Psikologi Universitas Gajah Mada. Yogyakarta. 218 hal.

Hibatul, T., Riniatsih, I., \&Azizah, R. 2013. Struktur Komunitas Zooplankton di Ekosistem Lamun Alami dan Berbagai Lamun Buatan Perairan Teluk Awur, Jepara. Journal of Marine Research, 2(4):16-22.

Krebs, C.J. 1972. The experimental analysis of distribution and abundance. Ecology. New York: Harper and Row.

Ludwig, J. A., Quartet, L., \& Reynolds, J. F. 1988. Statistical ecology: a primer in methods and computing. John Wiley \& Sons.

Odum, 1993. Dasar-dasar Ekologi. Edisi ke III. Diterjemahkan oleh Tjahjono, S. Gajah Mada University Press. Yogyakarta: $201-250 \mathrm{hlm}$.

Pizan, A. M., Utojo, U., Atmomarsono, M., Tjaronge, M., Tangko, A. M., \& Hasnawi, H. (2017). Potensi Lahan Budi Daya Tambak Dan Laut Dikabupaten Minahasa, Sulawesi Utara. Jurnal Penelitian Perikanan Indonesia, 11(5): 43-50.

Romimohtarto, K., \& Juwana, S. 2001. Biologilaut: Ilmu pengetahuan tentang biota laut. Djambatan.

Setyawati, Y. 2014. Hubungan Antara Kelimpahan Epifauna Dasar Dengan Tingkatan Kerapatan Lamun Yang Berbeda Di Pulau Panjang Dan Teluk Awur Jepara. Management of Aquatic Resources Journal, 3(4):235-242.

Simanjuntak, M. 2009. Hubungan faktor lingkungan kimia, fisika terhadap distribusi plankton di perairan Belitung Timur, Bangka Belitung. Jurnal Perikanan, 11(1):31-45.

Suryabrata, S. 1992. Metodologi Penelitian. Rajawali Press. Jakarta.

Yamaji, I. 1979. Illustration Of Marine Plankton of Japan. Hoikusha. Publishing Co, Ltd. Japan. 5-179pp. 